\title{
THE EVOLUTION OF GROCERY
}

\section{WHOLESALING AND GROCERY}

\section{WHOLESALERS IN IRELAND AND}

\section{BRITAIN SINCE THE 1930s}

\author{
Jim Quinn \\ School of Business Studies \\ Trinity College Dublin \\ Dublin 2 \\ Ireland \\ Tel: +353-1-6081339 \\ Email: James.Quinn@tcd.ie \\ and \\ Leigh Sparks \\ Institute for Retail Studies \\ University of Stirling \\ Stirling, UK. \\ Tel: +44-1786-467384 \\ Email: Leigh.Sparks@stir.ac.uk
}




\title{
THE EVOLUTION OF GROCERY WHOLESALING AND GROCERY WHOLESALERS IN IRELAND AND BRITAIN SINCE THE 1930s
}

\begin{abstract}
Studies of industry evolution are relatively scarce outside of industries defined by narrow technological bases. Studies of wholesaling are rarer still. These are curious features given that it is probable that service industries behave differently to manufacturing ones and that wholesaling is such a key function of many economies. This paper looks at the evolution of grocery wholesaling and grocery wholesalers in Ireland and Britain since 1930. It focuses on the processes and drivers of the wholesale industry. Similarities and differences between the two countries are discussed. Particular emphasis is placed on the role of government action as a triggering mechanism for change and on the role of trade associations and industry leaders in developing and following through on market and non-market strategies. The pathways of industry evolution identified differ from those seen in manufacturing. They therefore raise a number of issues for the development of understanding and conceptualisation in industry evolution studies.
\end{abstract}

Keywords: Grocery, Wholesaling, Wholesalers, Ireland, Britain, Industry Evolution, Government Action 


\section{THE EVOLUTION OF GROCERY WHOLESALING AND GROCERY WHOLESALERS IN IRELAND AND BRITAIN SINCE THE 1930s}

\section{Introduction}

The study of industry evolution has attracted growing interest among economists and management academics over the past twenty years, driven by the level of change experienced by many industries. The aim of this increasing body of research has been to develop models that explain the changes being observed. From this it is hoped that useful and practical help can be provided to practicing managers who struggle to manage the changes taking place.

However, the research agenda, to date, has been limited at a number of levels. Firstly, there has been a much stronger focus on studying industry demographics and to some extent industry dynamics rather than full blown studies of structural evolution. Secondly, there has been a strong bias in the choice of industries studied. For the most part, manufacturing industries, particularly ones with a strong technology content have predominated. The nonmanufacturing sector has been neglected, despite the growth of service industries and the prevalence and importance of distribution industries like wholesaling and retailing in the modern global economy. The outcome has been that our understanding of the process of industry level structural evolution has been limited.

This paper looks to expand our understanding of industry evolution by reporting on research that compares the evolution of grocery wholesaling in both Britain and Ireland. The paper asks: what are the main explanatory drivers of industry evolution and can a pattern of process be observed? By doing so it attempts to go some way towards redressing the research imbalance that currently marginalizes distribution industries. 


\section{The Process of Industry Evolution}

Most of the empirical studies that have been conducted, to date, have focused on manufacturing industries, particularly those defined by a narrow technological base. The outcome of this has been that the industry lifecycle has been identified, and remains, the main process model with empirical support. Industry lifecycle thinking has its origins in efforts to extend the product lifecycle to an industry level of analysis (Klepper, 1997). Abernathy and Utterback’s (1975) seminal paper explained patterns of innovation by linking the technology lifecycle and the process of industry evolution. Underpinning this was the proposition that technology based innovation was the primary driver of the evolutionary process. Much of the subsequent evidence used to support the lifecycle concept was thus drawn from studies covering industries like automobiles, typewriters, automobile tires, commercial aircraft, televisions and penicillin (Klepper, 1997).

However, the generic explanatory power of the lifecycle model (Abernathy and Utterback, 1975) was quickly challenged by Pavitt and Rothwell (1976) on the basis that it was 'not wholly consistent with the different patterns of innovation observed' (p. 377). Porter (1980) questioned the possibility of a generic model of process and called for more attention on underlying drivers. Mowery and Nelson (1999) noted the dangers of relying too much on 'theories of industry life-cycles that focus on the evolution of limited product classes'; and highlighted the lifecycle model's inability to explain the evolution of industries more widely defined than on a single technological base. Klepper (1997) observed that while the lifecycle concept works well in describing the formative eras of many industries, it does not capture fully the dynamics of the mature phase, particularly the issue of de-maturity. Furthermore, he also postulated that some industries do not, in fact, conform to the lifecycle model. The life 
cycle stages of maturity and decline have proved particularly problematic. This can be seen when trying to explain the evolution of older industries, particularly those that provide basic necessities such as food and construction materials. Such industries can be seen to reach a “mature” stage but not decline (Grant, 2005). Despite all of these inherent weaknesses, McGahan et al (2004: 2) have recently observed that 'the industry lifecycle model - is so widely accepted and its basic premises so taken for granted that it has become conventional wisdom in business'

There have been a number of attempts to expand the understanding of industry evolution outside of manufacturing. Barras (1986) proposed the existence of a reverse lifecycle for service industries. He suggested that service industries do not experience a technology driven take-off or introduction phase. Instead, new technologies start out as a means of increasing the delivery efficiency of existing services. Over time the new technology is applied to improving the quality of service before finally moving on to assist in generating wholly transformed or new services. As such, where manufacturing industries experience product innovation followed by process innovation, service industries experience a cycle of incremental process innovation followed by radical process innovation and finally product innovation.

This reverse lifecycle has found some support from Pandit and Cooke (2003) in their study of the British financial services industry and Aranda and Molina-Fernandes (2002) in their study of Spanish engineering consultancies. However, the reverse lifecycle has also been subjected to criticism. Langeard and Eiglier (1990) consider the model to be valid only for services with a substantial back-office. Petit (1990) sees the model's main area of strength to be in household services, which have a significant level of self-service while Gallouj (1998: 14) 
found it to be 'less a theory of innovation in services than a theory of the spread of technological innovation from manufacturers to services’. A more fundamental weakness, however, may be that Barras continues to focus on the role of technology rather than on a wider driver set.

In the distribution field Fein (1998), in his evolutionary study of US drug wholesaling, demonstrated that wholesaling differs from manufacturing type industries, with pre-existing theories of change applying unevenly, if at all. These issues have been taken up by Quinn and Murray (2005) and Quinn and Leavy (2005) in their study of the evolution of wholesaling industries in Ireland, in which they reveal no evidence of life cycle and identify an expanded range of evolutionary drivers.

It is clear that while lifecycle thinking offers a powerful way of explaining the process of industry evolution, within certain contexts it appears to be incomplete. McGahan et. al (2004), Ruef (2004) and Windrum (2005) have called for more fine grained studies of industries at maturity and regeneration as a way of extending understanding of later evolutionary stages. Others (e.g. Utterback 1994, Klepper 1997, Fein 1998, Quinn and Murray 2005, Quinn and Leavy 2005) point to the need to expand the range of studies to nonmanufacturing industries such as wholesaling and retailing. This paper responds to these calls.

\section{Wholesaling as a Research Domain}

Over twenty years ago, Dawson and Moir (1985) concluded their review of wholesaling in Great Britain by noting that "within government and academic groups, there is little recognition of the importance of wholesaling, despite its key position in the dynamic economy 
of distribution" (p20). They drew an important distinction between the acts and processes of wholesaling and the organisations that undertook these activities, some of which were wholesalers i.e. their primary function was wholesaling. They further note that "although the wholesaling sector is a major sector in the British economy, relatively little is known about the way it operates ... but from observation it is clear that the sector is undergoing rapid change" (p20).

In the intervening period, studies of wholesalers and wholesaling have become even less common. Rosenbloom attempted to breathe life into research on wholesaling in the USA, culminating in a 1994 special edition of the Journal of Marketing Channels (Rosenbloom 1994). However, this effort has not been sustained. In the UK research on wholesaling became effectively non-existent. This lack of both interest and understanding may have occurred in part because wholesaling activities have increasingly been undertaken by manufacturers, retailers or other channel organisations such as logistics services providers (Dawson and Shaw 1989, Fernie and Sparks 2004). Wholesaling as a dynamic supply activity has become a battleground for competing power and efficiency stratagems of manufacturers and retailers. In many product sectors it would appear that wholesaling is of critical importance in performance terms, but that wholesalers have become less visible, probably less significant and thus of less importance to study. This is not to say that wholesaler numbers have been in decline in every product sector, but rather that their economic significance has shifted. In order to survive and prosper wholesalers and the wholesale sector, like wholesaling as an activity, have changed. This makes the study of the industry evolution of wholesaling important and potentially significant. 
Dawson and Moir (1985) considered the British market. There is no doubt however that many of the changes and trends they identified occur also in other countries. There may be variation in the extent and timing of change by product sector and by country, but there is agreement that wholesale activities are increasingly blurred within supply and demand chains. Retailer-generated reconfiguration of supply systems in for example Japan, Korea, Poland, Spain or Ireland are affecting the stability and survival of traditional wholesalers, as well as affecting retail competition for consumers. There are thus comparative, international and global dimensions to research into wholesaling and wholesalers.

Wholesaling is a large and wide-ranging sector of most economies. Not all product sectors within wholesaling are undergoing the same set of changes at the same time, though there may be some consistent themes in the long run (Quinn and Murray 2005; Quinn and Leavy 2005). Grocery wholesaling is probably the largest wholesaling sector, and arguably the one most affected by change. Furthermore, whilst grocery wholesaling is important in itself, due to its scale and supply of products to meet basic needs, it is also significant because of the activities of major manufacturers and major retailers. As such the study of the grocery wholesaling sector potentially illuminates behaviours, affects, responses and futures for other wholesaling sectors.

This paper attempts to present and account for industry evolution in grocery wholesaling in Ireland and Britain since the 1930s, focusing on drivers and processes. A long-run approach is taken in order to evaluate the inter-acting affects of activities, changes, legislation and power struggles. The paper is primarily concerned with grocery wholesalers, but as noted above, understanding changes in grocery wholesalers requires accounting for changes in wholesaling itself and those undertaking wholesaling activities. The paper also considers in 
part about the changing nature of retailing and retail firms and their activities during this period.

The paper is divided into four further sections. First, the approach and methodology are presented. Some of this has been noted elsewhere (Quinn 2002; Quinn and Murray 2005; Quinn and Leavy 2005; Quinn and Sparks 2006). Secondly, a tabulated comparative synopsis of the case data is presented. Thirdly, a comparative discussion is provided. Finally, conclusions are drawn.

\section{The Research Approach and Methodology}

This research seeks to explore how context, social action and history interplay in driving and patterning the process of evolution in wholesaling over time. In doing so it employs a qualitative methodology based on multi-modal and multi-level approaches, focused on a long-time period. Few templates are available to guide inductive research into the dynamics of industry evolution using such approaches. This study adopted an approach akin in method and perspective to the contextualist research strategy developed for the Warwick studies on corporate change (Pettigrew 1987, 1990, 1997). It is thus informed by a number of principles:

- Multiple levels of analysis were used to connect context, process and outcome;

- An underlying theory of social action was employed;

- A longitudinal case-based research design was employed to allow patterns of continuity and change to be observed over time.

The data for Ireland were gathered primarily between 1997 and 2001, through archival material and personal interviews. The material reviewed included the minutes and records of industry associations, association newsletters, journal and publications; published and 
unpublished company and industry reports; government publications; newspaper records; published and unpublished industry histories and biographies; and industry statistics from census and commentator reports. Fuller details can be found in Quinn (2002).

The data for Britain were gathered primarily from 2002 to 2006 and, in essence, replicated the approach adopted in Ireland. Fewer interviews have been completed at this time and the research programme remains active in that regard. Data collection was enhanced by the considerable volume of secondary material available from both academic and archival sources (see appendix 1 for list of the academic sources not referenced elsewhere ${ }^{1}$ ). A particular trade source (the Institute of Grocery Distribution reports on Grocery Wholesaling, started in 1979 and published almost annually since) has been assembled as a complete data source in one place, apparently, for the first time. The main source used has been the trade magazine The Grocer (see similar use in Shaw et al 2004 and Alexander et al 2005), which has been read in its entirety from 1930 onwards with all references to wholesalers or wholesaling extracted to form a core part of the narrative of the full case ${ }^{2}$.

Case based research offers special challenges for journal authors and readers. The richness and quantity of data available sits uneasily within the confines of most journal guidelines on space. That said, the academic world is producing an increasing body of rich case research that can contribute much to our understanding of the business world. The dilemma is therefore finding a balance. Authors must find ways of presenting data in a way that captures the essence of their material and allows for sufficient 'feel' on the part of reader. This can often entail making painful decisions that balance detail and conciseness. This paper attempts to bridge this gap through a tabulated comparative synopsis that looks to provide sufficient data exposure for the reader together with a time line of events (Table 1). 
Table 1: Comparative Synopsis of the Case Studies: Grocery Wholesaling in Ireland and Britain since the 1930s

\begin{tabular}{|c|c|}
\hline BRITAIN & IRELAND \\
\hline $\begin{array}{l}\text { Starting Conditions } \\
\text { - } \quad \text { Approx 2,000 wholesalers with } 120 \text { larger ones } \\
\text { Both wholesalers and retailers are organised into local, } \\
\text { regional and national associations. The National Federation } \\
\text { of Wholesale Grocers (NFWG) was established in } 1918 \text {. } \\
\text { - Wholesalers service a market where independent retailers } \\
\text { have a 54\% market share. The rest is divided between } \\
\text { multiples (25\%) and the Co-op (20\%) } \\
\text { - There was intense price competition throughout the 1920s and } \\
\text { into the 1930s that led to significant margin erosion. }\end{array}$ & $\begin{array}{l}\text { Starting Conditions } \\
\text { - } \quad \text { Approx } 300 \text { wholesalers with } 25 \text { larger ones } \\
\text { They service a retail sector where independent retailers have } \\
75 \% \text { of the retail market and multiples command the other } \\
25 \% \\
\text { - There was intense price competition throughout the } 1920 \text { s and } \\
\text { into the } 1930 \text { s that led to significant margin erosion. }\end{array}$ \\
\hline $\begin{array}{l}\text { 1934 - 1945: Creating stable structures } \\
\text { - The intensity of price competition creates pressure to bring } \\
\text { order to the sector. } \\
\text { Manufacturers, wholesalers and retailers came together under } \\
\text { the banner of the Grocery Proprietary Articles Council } \\
\text { (GPAC) to enforce a system of Resale Price Maintenance. In } \\
\text { 1936 GPAC armed itself with rules and sanctions that would } \\
\text { allow them to stop supplies to 'errant' traders i.e. price } \\
\text { cutters. The restrictions of RPM were actively resisted by the } \\
\text { large retail multiples and by the Co-operatives. } \\
\text { In } 1937 \text { the Shops (Retail Trading Safeguards) Bill looked to } \\
\text { restrict the growth of multiples and protect independent } \\
\text { retailers. It failed due opposition from multiple and Co- } \\
\text { operative retailers and lack of support and political power } \\
\text { from wholesalers and independent retailers. However, the } \\
\text { growth of multiples and the Co-op slowed during the period. } \\
\text { WW2 brought shortages of goods and manpower, } \\
\text { Government control of prices and margins, and restrictions }\end{array}$ & $\begin{array}{l}\text { 1932 - 1945: A consolidation of power } \\
\text { - In } 1932 \text { a new government introduced a protectionist regime } \\
\text { that affected the importation of many grocery items. This } \\
\text { brought a new insularity to the sector that undermined } \\
\text { competitiveness and allowed some to extract excessive } \\
\text { profits. } \\
\text { - Following a period of intense price competition, } \\
\text { manufacturers' trade associations looked to enhance } \\
\text { profitability by pressing for lower distribution margins. In } \\
\text { response, the largest wholesalers, formed the Association of } \\
\text { Wholesale Grocers, Importers and Distributors (AWGID and } \\
75 \text { smaller wholesale firms set up the Wholesale Grocers } \\
\text { Association of Ireland (WGAI). } \\
\text { - Wholesaler associations won better terms from manufacturers, } \\
\text { stabilised prices and disciplined members who broke } \\
\text { association rules. The end result was a rigidly controlled } \\
\text { distribution system with tight control on pricing structures. } \\
\text { The Second World War brought price controls and rationing }\end{array}$ \\
\hline
\end{tabular}


on entry to the trade. GPAC focused on dealing with profiteering and assisting manufacturer members to maintain continuance of equitable distribution. The war favoured the independent sector and enhanced and consolidated the wholesaler's role.

\section{6 - 1953: A build-up of tensions}

- Rationing was slowly dismantled before ending in 1954

- The arrival of a new Labour government brought pressures for lower cost solutions in food distribution.

- Self-service was introduced in 1947 and encouraged by government but was slow to grow due to a licensing requirement for the building materials required to enable it.

- In 1947 a committee of inquiry was set up under the chairmanship of Mr. Justice Sir George Lloyd Jacob to investigate RPM. The committee criticised the role of RPM, Trade Association behaviour and GPAC.

- From the late 1940 s tensions were building in the wholesaler - retailer relationship. Wholesalers were seen to be resisting reform, opposing retail buying groups and appropriating retailer margins. Trade associations were central to maintaining a balance of power both within and between the various channel actors within the grocery sector.

- A survey of wholesaler costs revealed that wholesalers net profit before tax was under $2 \%$.

- Trade associations played a significant role throughout the 1950s in both promoting and retarding change. In 1953 Charles Green, the NFWG President, called for reform in wholesaling to reduce distribution costs and improve service to retailers. Herman Kent, the Secretary General of the Retailers Federation, called for closer co-operation between wholesaler and retailer to cut costs.

- A growing sense of grievance among retailers over terms and conditions of supply and margins saw the formation of the Retail, Grocery, Dairy and Allied Trades' Association (RGDATA) in 1942.

\section{6 - 1953: A build-up of tensions}

- Rationing ended in the 1940s and pent-up demand was released.

- New entrants emerged in both wholesaling and retailing, drawn by demand growth. These fell outside the existing structures and fermented a bout of price cutting.

- Growing price competition confronted a wholesale sector that had become inefficient and vulnerable to competition.

- RGDATA looked to ensure that wholesalers did not supply the newly emerging price-cutters.

- Tensions grew as wholesalers sought to protect their margins in the face of cut-price retailing and mixed retail-cumwholesale trading. The wholesaler associations found it increasingly difficult to maintain price discipline amongst their members. WGAI, in particular found it difficult as its membership included firms who were both wholesaler and retailer.

- Significant growth in branded goods and along with prepacked and processed foods led to an increase in the marketing activity of manufacturers, which they looked to fund through restructuring channel discounts, at the expense of wholesalers.

- Government concerns about escalating food prices from the late 1940s led to the introduction of the Restrictive Trades Practices Act (1953) and the formation of the Fair Trade Commission (FTC). 
- Visits to the USA organised by the Anglo-American Council and trade associations highlight the advantages of supermarkets, buying groups and group trading formats.

However, wholesalers were slow in adopting new methods

\section{4 - 1960: End of the old order and creating a new recipe}

- Manufacturers increased their marketing and product development activities and began to consolidate into larger groups. They also became less influenced by the need for RPM and GPAC.

- Retailing changed profoundly, as the move to self-service accelerated. Larger outlets began to emerge. Consolidation through acquisition began to take place within the multiples. Aggressive expansion and development marked out chains such as Victor Value, Fine Fare, Tesco and Sainsbury.

- The Co-op was the early pioneer in self-service with a 40-1 lead over independents in conversions..

- It was a traumatic period for independent retailers with large numbers collecting under the banners of wholesaler voluntary groups and retailer buying groups.

- New larger scale retailer buying groups were formed. The Private Grocers Merchandising Association (PGMA), Bulk Organised Buying (BOB) and Londis Grovisions had their origins in this period.

- In wholesaling, voluntary symbol groups and the cash and carry format were introduced.. In 1954, Peter Keevil Ltd. of London became the first wholesaler to introduce voluntary group trading. In 1957, Vye \& Son of Ramsgate became the first cash and carry wholesaler. These changes in wholesaling attracted new entrants, among which were a number of larger companies such as Booker and ABF (Weston) who would reshape the wholesaling landscape.

- In 1956 a Restrictive Practices Act banned collective

\section{4 - 1958: The ending of the old order}

- Cut-price competition continued to grow.

- Channel tensions led to the formation of two retailer owned wholesale buying groups AND and MNC.

- Early forms of self service began to appear. Self service was aided by the emergence of an emerging set of new product, process, materials handling and storage technologies.

- The FTC investigation destabilised the sector and manufacturers took advantage of the instability to restructure channel discounts.

- Rising tensions generated by indiscipline caused WGAI to break up. The more prominent members joined with AWGID to form the Irish Wholesale Grocers Association (IWGA) which had 46 members. They excluded smaller wholesalers and mixed traders deemed to be undesirable. This weakened its position in the subsequent reorganisation of the wholesale sector. IWGA was dominated by the larger wholesalers form AWGID and was led by its former president Reggie Knight. Knight fought and won an internal battle to direct the association's efforts towards retaining the status quo and in doing so delayed the efforts for change in wholesaling.

- The grocery sector was investigated by the FTC and in their 1956 report they recommended the abolition of Resale Price Maintenance (RPM). By 1958 it was abolished.

- Pricing was now based on volume, not function and new manufacturer discount structures extended 'wholesale prices' to larger retailers and co-operatives.

- The IWGA fought hard to retain the status quo. However, the 
- By the end of 1960 wholesaling had been transformed. It was generally believed that there were too many wholesalers and that it would be in their own interest if some of them merged. Also, the advent of voluntary group trading introduced new tensions into the Wholesalers Federation

\section{1 - 1975: Building the new formula}

- GPAC was disbanded in 1961 and Resale Price Maintenance formally ended in 1964.

- The rising cost of living and food prices kept the sector at the centre of both government and media attention.

- The latter part of this period became a land-use planning battleground as local planning authorities struggled to come to grips with the emergence of food superstores

- The level of concentration increased significantly at retail level, driven by escalating competition generated by the multiples. While the number of multiple branches declined by a third the size of stores increased dramatically, with 101 superstores opening between 1962 and 1975. Likewise cooperative branches fell by $45 \%$ and the number of independent food retailers almost halved.

- Trading stamps became a controversial competitive tool for multiple retailers during the period.

- The new wholesaling formats took hold and expanded their membership. Wholesalers increasingly joined voluntary groups or converted to cash and carry. By the mid 1960s Centra had over 30 wholesale members, MACE 27, SPAR 33, sentiment of government, manufacturing trade, and public opinion was now firmly on the side of change. The old era came to an abrupt end, Knight departed and a new generation of leaders willing to face the new realities took control of the IWGA.

\section{9 - 1973: Finding and building a new formula}

- From the late 1950s the relative position of wholesalers declined due to the rise of multiple operated supermarkets and retail owned co-operatives and their direct supply by manufacturers.

- The emergence of out-of town shopping centres facilitated the expansion of larger scale supermarkets

- Throughout the 1960s, manufacturers backed the multiples through direct deliveries and higher discounts.

- By the early 1960s, many of the leading wholesaling firms in the old order had closed.

- The IWGA fought back by establishing a trading vehicle (EDL) to promote group trading. However, it met with little success due to the diverse abilities of its membership, along with the limited writ that it held over the sector.

- Cash and carry wholesaling and voluntary group trading were introduced as the new "wholesaling" trading formats. Leading wholesalers such as Musgraves found their initial inspiration through study trips to British wholesalers.

- In 1960 Musgraves became the first firm to form its own voluntary group trading structure and adopt the cash and carry 
- Wholesalers unable to change or lacking sufficient scale either closed or were acquired. Merger and acquisition activity grew. Many took place between members of voluntary groups. A number of larger scale groupings emerged.

- By the mid-1970s each of the major symbol groups became dominated by the interests of a particular large wholesaler. E.g. APT with Weston, SPAR with Linfood Holdings, VG with Wheatsheaf and MACE/Wavy Line with Booker.

- Cash and carry was initially seen as a 'temporary' format for small grocers. However, from the mid-1960s it became a key area of development. Sites grew from 61 sites in 1961 to a peak of over 600 by 1971 . Many were developed by voluntary group wholesalers. Nurdin and Peacock emerged as the leading operator.

- In the late 1960s cash and carry operators began to form buying and marketing groups such as ICCG, Big ' $N$ ' and NEWGA. Symbol group operators began to brand their cash and carry operations under separate brand symbols. APT under the Capital banner, SPAR under Value Centre, VG under Trademarkets and MACE under Keencost.

- 1971 marked the end of entrepreneurial growth in cash and carry. Subsequent growth came from larger organisations in a position to raise capital. By 1975 Booker McConnell, Warriner \& Mason, Oriel and Linfood had create national networks. Restructuring saw the number of depots fall by 3\% but floor area grew by 39\%. Also, the top 10 firms now accounted for $60 \%$ of warehouse space.

- At the end of the period 1,500 wholesalers were trading. About 250 significant firms existed. Eight firms had emerged with $£ 100 \mathrm{~m}$. + turnovers.
- In 1961 50+ small wholesalers, refused admission to EDL, formed NWGA as a buying group.

- Seven wholesalers came together to operate the SPAR retail franchise and to create the Value Centre cash and carry chain. By 1973 these had come under common ownership as BWG Foods. Five other wholesalers formed an alliance to operate the MACE franchise.

- The remaining EDL members gathered under the Centra symbol. By 1965 the IWGA ceased to exist. In 1971, following closures and defections, most of the remaining firms in EDL joined with the MACE franchise operators to form AND to launch the Keencost cash and carry chain.

- Independent retail buying groups AND and MNC launched Londis and MNC as symbol groups.

- Cash and carry expanded with Value Centre being operated by SPAR wholesalers and Keencost by AND/MACE.

- By the early 1970s, the retail multiples had secured 33\% of the market. Meanwhile the number of independent retailers had fallen sharply and would continue to decline. By the early 1970s, the grocery wholesaling industry had been changed profoundly. The plethora of independent wholesalers had consolidated into four wholesaler groupings. Two of these, Musgraves and BWG, had clearly emerged as new industry leaders. 
1976 - 2005: Consolidation and evolution of the new order

- There was a further decline in the independent retail sector and a corresponding decline in the position of grocery wholesalers. This was the outcome of relentless growth among multiples, facilitated by favourable planning and competition regulations, and changing consumer demands.

- In 1977 Tesco led a switch from trading stamps to low pricing that changed the locus of supermarket competition.

- In the late 1970s large multiples were suspected of using their market power to force unjustified discounts from manufacturers. Wholesalers and smaller retailers believed that they were being unfairly disadvantaged by this action.

- Independent retailers and wholesalers looked to influence government with a view to restricting the growth of the multiples. However, they lacked cohesion and proved ineffectual as their trade associations had become increasingly toothless. In contrast, the multiples acted in consort and succeeded in convincing consumers and (the Thatcher Conservative) government that they were the 'consumers champion'.

- The Monopolies and Mergers Commission (1981) and the Office of Fair Trading (1985) confirmed the existence of 'unfair' discounts but chose not to act because multiples were believed to pass on the savings to customers. This bolstered the position of large multiple retailers.

- Planning controls were liberalised during the 1980s and this stimulated the growth of multiples by allowing the development of out-of-town superstores.

- Wholesaling consolidated through acquisitions and mergers, as many firms such as Weston, Ranks and RCA that entered wholesaling during the 1950s and 1960s decided to exit. Much of the consolidation was driven by Booker. In the late
1974 - 2005: Consolidation and evolution of the new order

- By 1974, wholesalers had substantial buying power through their respective groupings. They had also consolidated around the symbol group and cash and carry formats.

- Cash and carry dominated and group trading declined in the 1970s.

- The industry consolidated throughout the period as Musgraves and BWG grew to control over $70 \%$ of wholesaler sales. The remaining wholesalers in AND and NWGA eventually merged to form Aontas. Meanwhile, the retailer group MNC was acquired in 1984 by BWG while Londis continues to trade.

- A series of government investigations during the 1970s confirmed that manufacturer deliveries to the retail multiples' branches cost 3.8\% more than similar drops to wholesalers, yet the wholesalers continued to gain little consideration for this.

- During the 1970s and 1980s the leading retail multiples competed intensely for customers and new development sites, often at the expense of independent retailers. As the market became more competitive there were numerous firm exits, including Tesco, who had entered by acquisition in 1979 .

- In 1978, resentment boiled over. Michael Campbell of ANDMACE led a boycott of a Nestlé-owned supplier, forcing it to concede extra margin. Buoyed up by this success, a new wholesale association, the Irish Association of Distributive Trades (IADT), was formed in 1979. By 1980, it had extracted extra discount from 26 leading suppliers and won a permanent injunction preventing Tesco from below cost advertising.

- In 1982, pressure from IADT and the independent retailers association RGDATA triggered the introduction of new Local 
- The survivors in wholesaling did so through a mixture of acumen and fortitude. Some post-1970 new entrants like Bestway, Dhamecha, Makro, Musgraves and AG Parfett flourished in the new environment. In 2005 Bestway jumped the industry rankings with its acquisition of the major cash and carry chain Batleys.

- Market leader Booker faced strategic trauma in the late 1990s with the failure of a major structural reorganisation (Project Heartland). The company then exited both delivered wholesaling and food services. The delivered business, was sold to Palmer \& Harvey McLane while food services was sold to the South African group Bidvest and renamed 3663 Foodservice. Palmer \& Harvey McLane then emerged as the leader in delivered wholesaling. There was continuing success for the surviving pioneers of voluntary group trading such as James Hall \& Co., Capper \& Co., A. F. Blakemore Ltd., C.J. Lang Ltd and Appleby and Westwood through their SPAR wholesale and retail activities

- From the mid 1970s, grocery wholesaling initially gravitated towards the cash and carry format, reaching a peak of $74 \%$ of wholesale business in the early 1990s. However, the switch to convenience shopping revived the role of symbol group trading and delivered wholesaling, resulting in a marked shift back to $55 \%$. Furthermore, deliveries by cash and carry
- In 1984, IADT allied itself with RGDATA, in a combination of wholesale and independent retail interests arguably without precedent in Europe. After an aggressive and often acrimonious ballet with successive governments in 1987, the alliance secured the protection they were looking for in a new Restrictive Practices (Groceries) Order. This effectively prohibited below cost selling.

- During the 1980s the tide turned in favour of group trading. Musgraves re-segmented the market by introducing the SuperValu symbol for trolley shopping and Centra for convenience. Meanwhile, BWG developed SPAR as a convenience brand.

- In 1990s BWG introduced EUROSPAR for trolley shopping and also acquired the MACE franchise and developed it as a second convenience brand

- Beginning in the 1980s cash and carry began to decline in favour of group trading. While it remained a significant format it increasingly focused on non-retail customers such as caterers, pubs and other grocery outlets.

- The period from the early 1990s was generally good for symbol group trading and the wholesale sector. The protection afforded by the 1987 Groceries Order gave independent retailers more confidence in their survival. Many began to upgrade their stores and tie their fortunes to the leading symbol groups, which in turn had clear strategies for their formats.

- In 1997, Tesco re-entered the Irish market through the acquisition of Power Supermarkets and were followed soon 
- The consolidation amongst wholesalers has had repercussions for group trading. In the early 1970s there were 21 symbols operated by over 100 wholesalers, with 14 having over 1000 members. In 2005 there were 13 symbols with five having over 1000 members. Only SPAR and MACE are of substance. SPAR now functions through five wholesalers while MACE is operated by one. New symbol groups such as Costcutter, Premier and Lifestyle/Scandia have appeared and developed strongly.

- In the mid 1990s the liberalisation of planning was reversed and a new focus placed on town centre development. The multiples were forced to take a renewed look at smaller urban sites and this generated a rapid move into convenience stores and other local formats. This was accelerated by major takeovers, as in the case of Tesco. Such outlets now compete directly with voluntary group formats and other convenience stores .

- The Federation of Wholesale Distributors (FWD) and the Association of Convenience Stores both opposed the Tesco convenience takeovers. Together they lobbied hard for the current Competition Authority investigation into grocery retailing.

- The more recent findings of a Competition Commission (2000) inquiry into the industry, which looked for evidence of "monopolies that appear to operate against the public", suggested once again that little action would be taken against the leading retail businesses. Independent investigations into the industry have tended to conclude that while UK food retailers may use their power to "exploit" manufacturers and suppliers, the practice is good for the consumer because savings tend to be passed on through lower prices. As such, the government after by Aldi and Lidl.

- Economic prosperity and changing life styles also played a part. Unprecedented year-on-year growth in disposable incomes, an increase in both single households and married couples in the workforce led to resurgence in demand for convenience shopping. It also fuelled a dramatic expansion in the catering sector as eating out became a significant activity for a cash rich and time poor population. These trends helped to fuel a recovery in the position of wholesaling and wholesalers. Irish grocery wholesalers came to control over $40 \%$ of the national grocery market.

- By 2005 however the long-term pressure on the 1987 Groceries Order and concerns about high prices in Ireland brought about a review of its impact. In November 2005 the Groceries Order was abolished, although there remain restrictions on predatory pricing, enforceable via competition authorities. The outcomes of this step for the independent retail sector and its wholesaling symbol group managers are yet to be seen. 


\begin{tabular}{|l|l|}
\hline has not been minded to institute any remedies, fearing being & \\
accused of raising prices for consumers. A further inquiry & \\
announced in Spring 2006 will test this situation again. & \\
With the growth in the convenience sector the prospects for & \\
group trading looks reasonable. The recent acquisition of & \\
Londis by Musgraves and their decision to return their & \\
Budgen chain stores to independent ownership mean that & \\
further developments in group trading may lie on the horizon & \\
\hline
\end{tabular}




\section{Discussion of the Cases}

In examining the totality of change in the two countries, a similar phase pattern can be seen to emerge. While the phase progressions were clearly not as sharply defined as the time line aspect of the tabulated comparative synopsis, in both industries broadly similar evolutionary patterns have been followed, and in relatively synchronised time frames. These phases are reflected in the case table, mapped in Figure 1 and can be considered in the sequence in which they are observed.

\section{Structural Reinforcement}

During the 1930s grocery wholesaling was in the midst of a phase of structural reinforcement. In both countries leading firms were trying to re-establish stable trading structures and build clear demarcation lines around existing structures. This was characterised by the efforts to preserve and strengthen the existing industry structure in the face of emerging pressures for change. While there are specific differences between the two countries the aim is similar and the reliance on trade associations of varying kinds is shared. The war years served to enhance existing structures and make them more embedded. Actions were aimed at ensuring that the grip of the existing wholesale industry leaders continued to hold sway. The pressures for change remained below breakthrough level.

\section{Structural Tension}

During the early post-war years, there was a new phase of growing structural tension, characterised by the escalation of both change and reactionary pressures. Grocery wholesaler leaders intensified their efforts to protect and strengthen existing structures, individually and through trade association activity. Sector norms had become firmly established in areas such as the supply of goods, price structure, method and degree of competition and trading format. 
At the same time, the pressure for change in and around the industry was rising. Relations between retailers and wholesalers became more fractious in Ireland as both wholesalers and retailers adopted a more distrustful approach to each other. Consumer and retail buyers, suppliers, firms outside the leading groups, and government were all becoming increasingly dissatisfied with the existing restrictive practices.

\section{Structural Fracture}

The old order finally began to fracture as the constituency for change continued to widen and the pressure intensified. Once the stranglehold of the old leaders was loosened by the intervention of government, opportunities for others to seize the initiative were opened up. Firms that had long led grocery wholesaling began to be subjected to levels of price competition and margin reductions that they were no longer able to withstand given their cost structures. The "breakthrough” came earlier in Britain than Ireland. Wholesale innovators quickly moved to introduce new service technologies such as group trading and cash and carry. In Ireland the leading trade association continued to resist the emerging changes. Businesses in both countries learned from developments overseas. Britain learned from the USA, whilst Ireland learned, in turn, from the British experience. Nonetheless, both industries also saw their relative position decline as non-traditional relationships and practices began to emerge among channel members elsewhere along the market chain (direct sales by manufacturers, associative buying groups and larger self-service supermarkets operated by ever stronger retail multiples).

\section{Structural Reconfiguration}

The transition from the old to the new order took time. While wholesaling was in flux, some of the more enterprising firms set about restoring their fortunes, through the importation of 
new ideas, formats and service technologies. One feature of this period was the declining role of trade associations in both countries. The enhanced focus on the trading/commercial aspects of relationships served to undermine any broader solidarity. This new commercial focus allowed some wholesalers and independent retailers together to achieve economies of scale and scope.

Although there were some important new entrants, many of the firms that succeeded during this period were based around long-established players from within the traditional wholesaling groupings. As this phase progressed, increasing reconfiguration and consolidation occurred through mergers, acquisitions, strategic partnerships and exits. The new order began to take more definite shape, with a smaller number of larger organisations in both countries. New formats of symbol group trading and cash and carry wholesaling became firmly established. However, the management and investment costs associated with group trading (as well as their inherent tensions) took their toll and the lower cost format of cash and carry increasingly found favour with both retailer and wholesaler. At the end of this period the industries in both countries had arrived at a very similar market position.

\section{Structural Consolidation}

The new order continued to consolidate as the new wholesaling formats became more dominant. Both countries experienced an initially strong bias towards cash and carry that subsequently reversed as convenience shopping began to grow in importance. However, this period is one where the two countries had differing experiences in a number of areas, including collective action, regulatory position and industry leadership. 
In Britain, the retail multiples were given a clear path to dominance through decisions the British Government and regulatory authorities made in relation to both competition law and planning regulation. Furthermore, unlike the Irish situation, the British wholesale industry was unable to improve its margin position through collective action. During the 1970s and 1980s the role and power of the various independent sector trade associations largely dissipated as independent grocery retailing lost almost three-quarters of its national market share. Britain also experienced a considerable amount of “churn” among the leading wholesale companies, with Booker being the only leading survivor from the mid-1970s. This industry flux made it difficult for "statesmanship” activity

In contrast, the Irish wholesalers re-established an effective forum for collective action (IADT) during the late 1970s. This new association was led by a succession of industry “heavyweights”. Having successfully used this forum to recover wholesalers’ margins, it set its sight on demanding Government protection for the independent retailing trade and thus its supplying wholesalers. By co-opting the independent retailer association RGDATA, the combined IADT/RGDATA became one of the most effective lobbying groups in the country. Through concerted political action the twin goals of both planning and competitive restrictions on multiple traders were achieved. Musgraves and BWG then consolidated their position through superiority in strategy, management and capital.

By avoiding a rapid decline in market share in the 1980s and by subsequently winning a regulatory umbrella, the independent sector in Ireland remained vibrant enough to capitalise rapidly on the emergence of the trend towards convenience. With strong consistent leading companies (albeit basically only two of them) applying coherent strategies, the wholesale 
sector revived and strengthened. In contrast, the British industry was severely weakened over the period with strong multiple retailer competition and inconsistent consolidation activities.

The cases can also be considered in the light of the issues raised by the literature on industry evolution studies. The industry life-cycle model appears to be of limited use in explaining the pattern of industry evolution that emerges from this study. The pattern observed may represent either an insight into the process of maturity and de-maturity within a very elongated lifecycle or a distinct pattern of process in its own right. The age of the industries, which exceed 150 years at this stage, makes such a judgement difficult. The two industries had already been founded and reached a stage of maturity by the start of the period considered here.

The life-cycle model is a deterministic perspective that provides little role for actors other than firms and drivers other than technology. As such, it does not account for the important role played by government, trade associations, co-operation and individual actors, all of which are identified in this study. There is also the presence of what amounts to new cycles of innovation during maturity. The data in this study tend to support the Mowray and Nelson (1999) view that 'theories of industry life-cycles that focus on the evolution of limited product classes are of limited use' in cases where the period covered is long and the product range is wide. It also highlights the inadequacy of the life-cycle model in addressing industry change during maturity and de-maturity.

There is some evidence to support the notion of a reverse technological lifecycle effect. This study demonstrates the way that technologies that emerged from the manufacturing sector initially acted to promote greater process efficiencies within both wholesaling and retailing. 
These escalated over time into new product propositions. The pattern observed is more in line with the proposition that enabling technologies go beyond a single technology. What is seen here is the emergence over time of a diverse set of enabling technologies from within the manufacturing sector, that acted to both drive and facilitate innovation within downstream service industries. The need for more detailed process modelling of this stage provides a fruitful focus for further research.

In terms of drivers of evolution a number of specific themes and some wider generalisations from the cases are suggested. First, the role of Government actions in relation to both competition and to local planning has played a key part in the industry outcomes.

Government can significantly alter the direction of industry evolution through their action or inaction.

Secondly a key factor would seem to be the presence or absence of collective action. Throughout the period wholesalers have relied extensively on co-operation as well as competition for their development. Some of this activity has been for competitive reasons, in areas such as the operation of symbol groups and to increase purchasing scale. However, on other occasions trade associations have been used to bring stability and to create political and social leverage. Both of these issues have been central to the story of the escalating rate of inter-channel competition.

Thirdly, scale has been important in the development and execution of strategy. Activity aimed a building a small number of well positioned, independent retailer operated, national convenience brands has been critical, though building this scale on a consistent basis both vertically and horizontally has not been straightforward. Despite this however the relative 
size of wholesalers when compared with major retailers or indeed manufacturers remains small. Scale has in turn had to be allied to operational efficiency and appropriate use of resources. For major retailers this has meant by-passing wholesalers and carrying out or organising the wholesale activities themselves.

Fourthly, market based strategies on their own are not enough to successfully compete. It is also necessary to develop and engage with non-market strategies. The development of political power and influence has been important in the maintenance of the wholesaling sector in Ireland. In Britain such power has been mainly absent and it is only recently that activities of this form have become more coherent.

Finally, there is the issue of time. The creation of a set of structures and of businesses within these structures takes time. However, most structures also have within them the seeds of their own destruction. Considerable effort has thus to be spent on maintaining existing situations. If this is not done, then there would seem to be a tendency for structures to be undermined. Time of course takes its toll on businesses and individual managers. Currently in Ireland, one could argue that dazzled by market success, turnover size and other scale elements, wholesalers and independent retailers have forgotten the value of non-market strategies and have allowed other influences to drive the political process, thus potentially undermining their success.

\section{Conclusions}

Overall this examination of grocery wholesaling in Ireland and Britain since the 1930s suggests that there is a discernable pattern of industry evolution. However, it is a pattern of regeneration rather than of lifecycle. Furthermore, this evolutionary process is driven by 
important factors other than technological breakthrough. All of this suggests that the industry life cycle model needs to be reconsidered to accommodate significant finer-grained patterns within the so called 'maturity’ phase.

There are some wider observations to be made in conclusion. First, we believe that the wholesaling industries examined here demonstrate again (see Fein 1998) that the patterns and processes of industry evolution in this service market are different to those in manufacturing or technology based industries. For example, the use of collective action for commercial purposes differentiates the evolution of wholesaling from that of many manufacturing industries. The way in which industry consolidation and concentration are managed and achieved, again appears very different.

Secondly, if wholesaling (or service sectors) is different then we need to develop the correct lenses through which to understand their evolution. Quinn and Murray (2005) have pointed to the potential of evolutionary approaches for conceptualisation of industry change, but have also noted that other more established approaches within organisation theory at the ecological level may also have value. Multi-faceted conceptualisations of wholesale industry change are needed.

Finally, there are of course disparities between Ireland and Britain. There is clearly a scale issue in economy terms as well as some differences in political, social, technological and economic systems and behaviours. Some of the issues we have highlighted reflect perhaps the abilities to achieve results in smaller markets. Others would appear to be common trends. It would be a major step forward if similar studies, taking similar approaches, but focused on grocery wholesaling in other countries e.g. USA, Japan, in Central and Eastern Europe, South 
Africa could be undertaken. By examining the dynamics of processes and patterns in industry evolution across countries strides may be taken in conceptualising and understanding the issues and the subject. We believe this is much needed.

\section{Notes}

1 - There is a paper to be written utilising the extensive research published to date on retail change in Britain during the period under consideration here, and the British case material developed during this research programme. However, this is not that paper. In order to compare the British and Irish cases, which is the main focus of this paper, in the space permitted, we have had to shelve that discussion in favour of a non-referenced tabular case study approach.

2 - The authors would like to thank the Institute of Grocery Distribution for allowing access for Jim Quinn to their resource centre containing this extensive run of The Grocer. It is possible that this source is not going to be available in a similar way in the future. To quote Joni Mitchell “You don’t know what you've got till it's gone”.

\section{Acknowledgement}

Part of the development of this paper was undertaken when Leigh Sparks was a Visiting Professor at the Department of Retail, Hospitality and Tourism at the University of Tennessee at Knoxville. 


\section{References}

Abernathy W J and Utterback JM (1975) A dynamic model of product and process innovation, Omega, 3, 639-659.

Alexander A, Shaw G and Curth L (2005) Promoting Retail Innovation: knowledge flows during the emergence of self-service and supermarket retailing in Britain, Environment and Planning A, 37, 805-821.

Aranda D and Molina-Fernandes LM (2002). Determinants of innovation through a knowledge-based theory lens, Industrial Management and Data Systems, 102, 5/6 289-96.

Barras R (1986) Towards a theory of innovation in services, Research Policy, 15, 161-173.

Dawson JA and Moir CB (1985) Wholesaling in Great Britain. Report prepared for The Distribution Policy Research Institute, Tokyo. Institute for Retail Studies, University of Stirling, Stirling.

Dawson JA and Shaw SA (1989) The Changing Characteristics of Retail-Supplier Relationships, in Fernie J (ed) Retail Distribution Management, Kogan Page, London.

Fein A (1998) Understanding Evolutionary Processes in Non-Manufacturing Industries: empirical insights from the shakeout in pharmaceutical wholesaling, Journal of Evolutionary Economics, 8, 231-270.

Fernie J and Sparks L (eds) (2004) Logistics and Retail Management. Second edition. Kogan Page, London.

Fulop C (1962) Buying by Voluntary Chains. George Allen \& Unwin, London.

Gallouj F (1998) Innovation in reverse: services and the reverse product cycle, European Journal of Innovation Management, 1,3, 123-140.

Grant R (2005) Contemporary Strategy Analysis (5 ${ }^{\text {th }}$ Ed.), Blackwell.

Klepper S (1997) Industry Lifecycles, Industrial and Corporate Change, 6, 1, 145-181.

Langeard E and P Eiglier (1990) L’innovation de service (Service Innovation), Working Paper, University of Aix-Marseille III, March.

McGahan AM, N Argyres and Baum JAC (2004) Context Technology and Strategy: Forging New Perspectives on the Industry Lifecycle in Baum JAC and McGahan AM (eds) Business Strategy over the Industry Lifecycle: Advances in Strategic Management, Vol. 21, Elsevier JAI: Oxford p. 1-21.

Mowery DC and Nelson RR (1999) Explaining Industrial Leadership, in Mowery DC and Nelson RR (eds) Sources of Industrial Leadership: Studies of Seven Industries, Cambridge University Press, 359-382. 
Pandit R and Cooke G (2003) The benefits of industrial clustering: Insights from the British financial services industry at three locations, Journal of Financial Services Marketing, 17, 3, 230-246.

Pavitt K and Rothwell R (1976) A Comment on 'A Dynamic Model of Process and Product Innovation', Omega, 4, 375-377.

Petit P (1990) Employment, productivity and information technologies: the case of service industries', IRIS Conference, University of Paris XI Dauphine "Competence and Competitiveness", April.

Pettigrew AM (1987) Context and Action in the Transformation of the Firm, Journal of Management Studies, 24, 649-70.

Pettigrew AM (1990) Longitudinal Field Research on Change: Theory and Practice, Organization Science, 1, 267-92.

Pettigrew AM (1997) What is Processual Analysis? Scandinavian Journal of Management, 13, 337-48.

Porter ME (1980) Competitive Strategy, New York: The Free Press.

Quinn J (2002) Industry Evolution - a comparative study of Irish wholesaling. Unpublished PhD Thesis, Dublin City University.

Quinn J and Murray JA (2005) The Drivers of Channel Evolution: a wholesaling perspective, International Review of Retail, Distribution and Consumer Research, 15, 3-25.

Quinn J and Leavy B (2005). The Drivers of Industry Evolution: A Study of Irish Wholesaling, Journal of Marketing Channels, 13, 1, 37-62.

Quinn J and Sparks L (2006) Institutional Change in Grocery Wholesaling in Britain and Ireland: The Role of Government Activism. Paper presented to the Strategic Management Society Conference, Vienna, November.

Rosenbloom B (ed) (1994) Wholesale Distribution Channels: New Insights and Perspectives, The Haworth Press.

Ruef M (2004) 'For whom the bells toll: ecological perspectives on industrial decline and resurgence’, Industrial and Corporate Change, 13, 1, 61-89.

Shaw G, Curth L and Alexander A (2004) Selling Self-Service and the Supermarket: the Americanisation of food retailing in Britain 1945-1960, Business History, 46, 568-582.

Utterback J (1994) Mastering the Dynamics of Innovation. Harvard Business School: Boston, MA.

Windrum P (2005) Heterogeneous preferences and new innovation cycles in mature industries: the amateur camera industry 1955-1974, Industrial and Corporate Change, 14, 6, 1013-1074. 


\title{
Appendix 1: Academic sources consulted the development of the British case study
}

\author{
Alexander A (2002) Retailing and Consumption: evidence from war time Britain, \\ International Review of Retail, Distribution and Consumer Research, 12, 39-57.
}

Alexander A, Benson J and Shaw G (1999) Action and Reaction: competition and the multiple retailers in 1930s Britain, International Review of Retail, Distribution and Consumer Research, 9, 245-259.

Burt SL and Sparks L (2003) Power and Competition in the UK Grocery Market, British Journal of Management, 14, 237-254.

Collins A, Burt SL and Oustapassidis K (2001) Below-Cost Legislation and Retail Conduct: evidence from the Republic of Ireland, British Food Journal, 103, 607-622.

Davies BK and Sparks L (1989) The Development of Superstore Retailing in Great Britain 1960-1986: evidence from a new database, Transactions of the Institute of British Geographers, 14, 74-89.

Jeffreys JB (1954) Retail Trading in Britain, 1850-1950. Cambridge University Press, Cambridge.

Lord D, Moran W, Parker AJ and Sparks L (1988) Retailing on Three Continents: the discount food store operations of Albert Gubay, International Journal of Retailing, 3(3), 354.

Morelli C (1998) Constructing a Balance between Price and Non-Price Competition in British Multiple Food Retailing, 1954-1964, Business History, 40 (2), 45-61.

Shaw G and Alexander A (2006) Interlocking Directorates and the Knowledge Transfer of Supermarket Retail Techniques from North America to Britain, International Review of Retail, Distribution and Consumer Research, 16, 375-394.

Shaw G, Alexander A, Benson J and Hodson D (2000) The Evolving Culture of Retailer Regulation and the Failure of the Balfour Bill in Inter-War Britain, Environment and Planning A, 32, 1977-1989.

Sparks L (1990) Spatial-Structural Relationships in Retail Corporate Growth: a case study of Kwik Save Group P.L.C. Service Industries Journal, 10(1), 25-84.

Sparks L (1994) Consumer Co-operation in the United Kingdom 1945-1993. Journal of Cooperative Studies, 79, 1-64.

Wood S, Lowe M and Wrigley N (2006) Life after PPG6 - recent UK food retailer responses to planning regulation tightening, International Review of Retail, Distribution and Consumer Research, 16, 23-41. 
Figure 1: The Path of Industry Change in Grocery Wholesaling

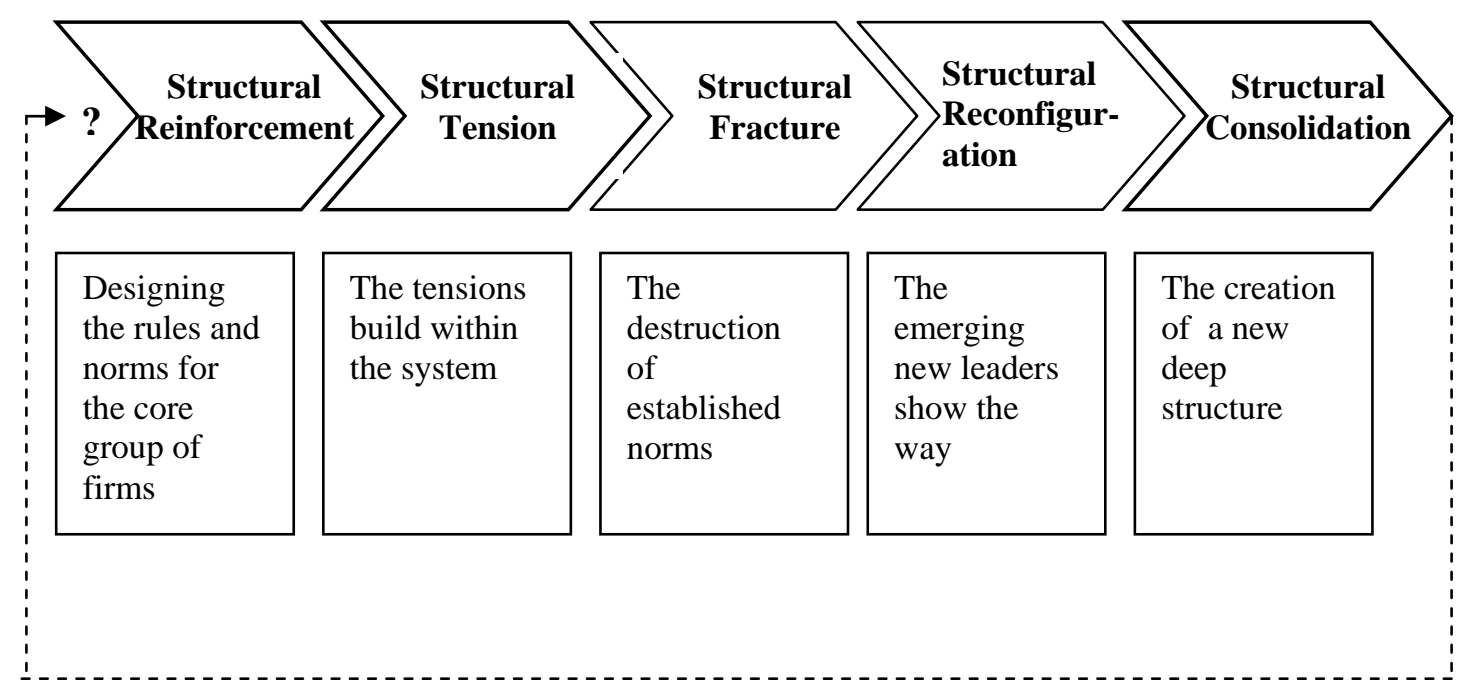

